\title{
IMPLEMENTASI SUSTAINABILITY SEBAGAI ALAT PEMASARAN PADA ERA PANDEMI COVID-19
}

\author{
Six Finish Wella ${ }^{1}$, Chairy $^{2}$ \\ ${ }^{1}$ Program Studi Magister Manajemen, Universitas Tarumanagara Jakarta \\ Email: sixfinishwella@gmail.com \\ ${ }^{2}$ Fakultas Bisnis, President University Bekasi \\ Email: chairy@president.ac.id
}

Masuk : 28-06-2020, revisi: 24-07-2020, diterima untuk diterbitkan : 24-07-2020

\begin{abstract}
ABSTRAK
Kepedulian terhadap lingkungan dan dampak sosialnya terhadap bisnis telah menjadi isu utama di berbagai organisasi saat ini. Pelanggan telah semakin sadar dan menghendaki produk yang ramah lingkungan. Karenanya, banyak perusahaan yang kemudian berusaha memenuhi keinginan konsumen dengan menerapkan sustainability marketing. Namun demikian tidak semua perusahaan peduli dengan isu ini. Beberapa perusahaan menggunakan sustainability marketing sekedar untuk meningkatkan pendapatan perusahaan. Objek penelitian pada artikel ini adalah sustainability marketing. Secara spesifik, artikel ini membahas tentang keberadaan sustainability marketing, tipe perusahaan dari sisi komitmen dan gaya komunikasinya, dan relevansi sustainability marketing sebagai alat pemasaran dalam situasi bisnis yang tidak pasti karena pandemi Covid-19. Subyek penelitian pada artikel ini adalah dua perusahaan besar di Indonesia. Lebih lanjut, Covid-19 telah mengubah perilaku konsumen dalam kaitannya dengan belanja online dan kesadaran akan isu sosial dan lingkungan atas produk yang dikonsumsi. Dengan menggunakan pendekatan kualitatif, artikel ini memperlihatkan efektivitas sustainability marketing. Dengan mengadopsi sustainability marketing banyak perusahaan tidak hanya akan berhasil melewati masa sulit karena pandemi Covid-19 namun juga akan memenangkan persaingan di masa depan.
\end{abstract}

Kata Kunci: sustainability marketing, alat pemasaran, Pandemi Covid-19

\begin{abstract}
Nowadays, environmental concerns and its social impacts on business have become major issues in most of organizations. Customers have become more aware and demand for more environmentally friendly products from companies. Therefore, many companies have been trying to answer the demand by using sustainability marketing in running the business. However, not all companies are concerned about the issues. Some of them only using green and sustainability concept as a tool to increase their revenue. The object of this research is sustainability marketing. Specifically, this article explores more about sustainability marketing, types of companies in terms of their commitment and communications related to sustainability marketing, and the relevance of sustainability marketing as a marketing tool in this uncertainty situation due to Covid-19 pandemic. The subject of this research is two big companies in Indonesia. Further, Covid-19 pandemic has changed consumer behavior in terms of online buying and awareness of environmental and social issues about products they consume. Using qualitative approach, this article shows the effectiveness of sustainability marketing. By adopting sustainability marketing, many organizations will not only survive the Covid-19 pandemic, but also win further competiton.
\end{abstract}

Keywords: sustainability marketing, marketing tool, Covid-19 pandemic

\section{PENDAHULUAN}

\section{Latar Belakang}

Skillful marketing adalah sebuah perjalanan yang tidak ada ujungnya, bisnis terus beradaptasi dan menyesuaikan dengan perubahan kondisi yang ada (Kotler \& Keller, 2016). Apabila sebelumnya traditional marketing merupakan salah satu strategi yang umum digunakan pada masanya, saat ini telah banyak bisnis yang mulai mengkombinasikann ya bahkan beralih ke digital marketing. Hal tersebut dikarenakan pelanggan juga mengalami perubahan perilaku. Dengan adanya kemajuan teknologi, masyarakat semakin lebih mudah untuk mencari informasi salah satunya dari sumber online. Kondisi ini jugalah yang mempengaruhi perubahan strategi pemasaran perusahaan. 
Perubahan perilaku tidak hanya terjadi pada bagaimana pencarian informasi dilakukan namun juga pada bagaimana masyarakat bereaksi terhadap informasi yang didapatkan. Jeevan (2016) mengatakan bahwa "environmental concern and social impacts of business is always a serious issue in today's day organization." Hal ini tidak terlepas dari peran media yang menginformasikan tentang kondisi lingkungan saat ini seperti isu global warming, lapisan ozon yang semakin menipis, efek rumah kaca (green house effect) dan isu lingkungan lainnya yang turut mengubah pola pikir konsumen. Karenanya, green consumer menjadi semakin popular saat ini. Green consumer merupakan konsumen yang peduli terhadap lingkungannya (Chairy \& Alam, 2019). Lebih jauh, selain green consumer, saat ini terbentuk persepsi bahwa segala sesuatu yang menggunakan kata green dipandang bersahabat dengan lingkungan dan memiliki nilai yang lebih tinggi (Syahrivar \& Ida, 2019). Konsekuensinya, pemasar juga perlu berusaha untuk menyesuaikan strategi pemasaran mereka sehingga dapat menjawab dan memenuhi permintaan pelanggan seperti dengan menggunakan green marketing dan sustainability marketing.

Saat ini, pelanggan telah semakin menyadari pentingnya menjaga lingkungan, membuat lingkungan di sekitar menjadi lebih baik, dan menerapkan gaya hidup yang lebih sehat sehingga mendorong mereka untuk lebih memilih produk yang ramah lingkungan atau tidak membahayakan bagi lingkungan sekitar (Bhaskar, 2013). Kesadaran tersebut juga datang dari pemerintah yang terbukti dengan kebijakan dan regulasi yang dikeluarkan bagi perusahaanperusahaan khususya untuk perusahaan yang terekspos langsung dengan lingkungan seperti pertambangan. Namun disisi lain, pemerintah juga memberikan insentif bagi perusahaan yang telah menjalankan praktik-praktik untuk mendukung isu pelestarian lingkungan salah satunya adalah dengan memberikan "Sustainable Business Reward".

Dengan adanya tuntutan eksternal dan perubahan pola hidup serta cara berpikir masyarakat tentang lingkungan, banyak perusahaan yang telah memulai menggunakan konsep sustainability sebagai bagian dari strategi dalam menjalankan kegiatan usaha salah satunya melalui program Corporate Social Responsibility (CSR). Salah satu alasannya adalah karena pelanggan lebih tertarik untuk membeli produk dari perusahaan yang memiliki tanggung jawab sosial (Pearce II \& Robinson Jr., 2015). Tidak hanya melalui program CSR, perusahaan juga menggunakan konsep sustainability dalam proses kegiatan usaha seperti menciptakan produk yang ramah lingkungan, menggunakan teknologi yang tidak merusak lingkungan termasuk pengelolaan limbah produk perusahaan sehingga tidak merusak lingkungan. Sustainable initiatives tersebut diharapkan dapat membantu perusahaan untuk meningkatkan brand image sehingga menarik perhatian calon pelanggan untuk membeli produk.

Saat ini dunia sedang dihadapkan pada krisis yang disebabkan oleh pandemi Covid-19. Untuk menekan jumlah penyebarannya, telah dikeluarkan bebagai macam kebijakan seperti social distancing dan physical distancing sehingga memaksa masyarakat untuk membatasi aktivitas mereka di luar. Hal tersebut menciptakan kebiasaan baru bagi masyarakat pada umumnya atau yang lebih dikenal dengan istilah the new normal dimana masyarakat lebih banyak melakukan kegiatan di dalam rumah termasuk tidak terbatas pada bekerja dari rumah (work from home), melakukan kegiatan belajar mengajar secara online, mengurangi bepergian ke tempat umum, mengurangi penggunaan transportasi umum serta melakukan belanja untuk kebutuhan sehari-hari atau barang-barang lainnya secara online. 
Meskipun disisi lain pandemi Covid-19 menyebabkan kerugian dari disisi material maupun nonmaterial, namun tidak dapat dipungkiri bahwa pandemi Covid-19 juga memberikan dampak yang positif terhadap lingkungan. Contohnya, laporan Pusat Perubahan Iklim - Badan Meteorologi Klimatologi dan Geofisika (BMKG) menunjukkan bahwa dengan melakukan kegiatan \#DiRumahAja, udara di Jakarta membaik (Mukhaer, 2020). The new normal dan dampak positif yang dirasakan oleh masyarakat dapat merubah pola pikir masyarakat terhadap pentingnya menjaga lingkungan. Oleh karena itu, pembahasan tentang pelestarian lingkungan di era new normal menjadi menarik. Penggunaan konsep sustainability dalam memasarkan produk di era new normal atau pasca pandemi Covid-19 menjadi sesuatu yang relevan.

Menurut Baldassarre \& Campo (2016), konsep sustainability dan pemasaran saling bertentangan karena sustainability dapat dicapai dengan mengurangi konsumsi sedangkan tujuan dari pemasaran adalah untuk meningkatkan konsumsi. Lebih lanjut Baldassarre \& Campo (2016) menjelaskan bahwa konsep tersebut tidak sepenuhnya benar karena konsep sustainability telah muncul sebagai salah satu paradigma dalam pemasaran selama beberapa tahun terakhir. Berikut adalah beberapa konsep terkait dengan sustainability marketing dan green marketing yang pada umumnya dianggap sama namun memiliki perbedaan.

\section{Green Marketing}

Bhaskar (2013) menjelaskan bahwa green marketing berkaitan erat dengan pengembangan produk berkualitas untuk memenuhi kebutuhan dan keinginan pelanggan dengan berfokus pada quality, performance, pricing dan convenience yang ramah lingkungan. Green marketing merupakan strategi pemasaran yang lebih difokuskan pada pemasaran produk-produk yang ramah lingkungan untuk mendapatkan profit bagi perusahaan. Lebih lanjut Bhaskar (2013) menjelaskan bahwa konsep green marketing mengalami perkembangan dan terdiri dari 3 tahap, yaitu:

1. Ecological Green Marketing - periode dimana seluruh aktivitas marketing difokuskan pada mengatasi permasalahan lingkungan dan melakukan upaya-upaya untuk mengatasi permasalahan tersebut.

2. Environmental Green Marketing - perubahan fokus kepada penggunaan teknologi yang lebih bersih dan ramah lingkungan serta pengembangan produk yang lebih ramah lingkungan sehingga dapat mengatasi permasalahan terkait dengan polusi dan limbah yang dihasilkan.

3. Sustainable Green Marketing - pengembangan produk berkualitas untuk memenuhi kebutuhan dan keinginan customer dengan berfokus pada quality, performance, pricing dan convenience yang ramah lingkungan

Pada dasarnya, konsep green marketing berfokus pada pengembangan dan penjualan produk yang lebih ramah lingkungan. Dahulu konsep green marketing dalam penjualan produk tidak popular seperti beberapa tahun terakhir ini. Namun karena perkembangan teknologi dan informasi yang cepat, saat ini telah banyak perusahaan yang mengikutsertakan konsep tersebut dalam kegiatan usaha yang dijalankan. Hal tersebut tidak terlepas dari peran perusahaanperusahaan besar seperti Walmart, General Electronic dan DuPont (Unruh \& Ettenson, 2010) yang mulai memperkenalkan going green companies. Unruh \& Ettenson (2010) menjelaskan bahwa terdapat 3 strategi yang dapat digunakan oleh perusahaan untuk going green:

1. Accentuate - An accentuate strategy involves playing up existing or latent green attributes in your current portfolio. Accentuate merupakan strategi yang paling umum digunakan yaitu dengan menambahkan unsur green pada produk tersebut. Sebagai contoh sebuah perusahaan memproduksi dan menjual kosmetik. Kemudian perusahaan memutuskan untuk going green, salah satunya dengan penggunakaan kemasan daur ulang untuk produk mereka. Perusahaan juga 
memberikan insentif bagi pelanggan yang mengembalikan kemasan produk kosong sehingga dapat digunakan kembali oleh perusahaan setelah melalui proses daur ulang.

2. Acquire - Apabila strategi accentuate tidak memungkinkan untuk diterapkan, maka perusahaan dapat menggunakan strategi yang kedua yaitu acquire dimana perusahaan membeli merk perusahaan lain yang telah going green seperti yang dilakukan oleh L'oreal yang membeli The Body Shop dan Unilever yang membeli Ben \& Jerry's.

3. Architect-Bagi perusahaan yang suka untuk berinovasi dan memiliki aset yang cukup untuk melakukan pengembangan, maka membangun dan melakukan inovasi green product dari titik nol dapat menjadi strategi yang tepat. Meskipun architect membutuhkan waktu yang lebih lama dan biaya yang tidak sedikit, namun strategi ini dapat menjadi strategi yang paling cocok untuk diterapkan pada beberapa perusahaan karena memaksa perusahaan tersebut untuk membangun kompetensi yang kompetitif.

\section{Sustainability Marketing}

Sustainability marketing tidak hanya berfokus pada produk dan penjualan yang ramah lingkungan namun merupakan pendekatan sistem secara keseluruhan yang lebih strategis dan berorientasi jangka panjang sehingga diharapkan perusahaan yang menerapkan strategi ini dapat mempertahankan eksistensinya (Farez, 2018). Untuk menerapkan sustainability marketing, perusahaan perlu mempertimbangkan dampak strategi tersebut tidak hanya dalam sudut pandang ekonomi seperti profitabilitas perusahaan, namun juga dampak secara sosial. Dalam penerapannya, sustainability marketing memiliki fokus pada tiga hal (3P) yaitu people, planet dan profit (Jeevan, 2016). Berbeda dengan konsep green marketing yang hanya berorientasi pada mengurangi dampak buruk terhadap lingkungan, sustainability marketing mencoba untuk mengikutsertakan seluruh aspek dalam perusahaan.

Dewasa ini, konsep sustainability marketing telah menjadi konsep umum dan menjadi topik menarik khususnya bagi para pelaku bisnis. Hal tersebut tidak lain dikarenakan semakin banyaknya pihak yang sadar tentang pentingnya integrasi antara menjaga eksistensi perusahaan dan pelestarian lingkungan. Selain itu, masyarakat yang semakin menyadari tentang pentingnya isu lingkungan juga memberikan tekanan tersendiri bagi perusahaan-perusahaan untuk terlibat baik secara langsung maupun tidak langsung dalam proses pelestarian lingkungan. Pelanggan dan pemasar akhirnya juga semakin menyadari dan sensitif terhadap kebutuhan produk dan layanan yang lebih ramah lingkungan (Bhaskar, 2013).

Tantangan selanjutnya yang muncul khususnya bagi para pelaku industri adalah bagaimana mereka sebaiknya menjalankan konsep sustainability marketing tersebut. Baldassarre \& Campo (2016) mencoba untuk menjelaskannya dari sudut pandang commitment dan communication yang dianalogikan dengan istilah dalam geologi yaitu kemampuan benda dalam menyerap dan memantulkan cahaya (Tabel 1). Informasi diibaratkan seperti cahaya dimana pengetahuan yang disampaikan oleh perusahaan sehubungan dengan inisiatif sustainable baik yang diimplementasikan atau tidak diimplementasikan oleh perusahaan kepada stakeholdernya melalui berbagai media. Pada opaque, diibaratkan cahaya tidak dapat menembus permukaan. Translucency dapat ditembus cahaya namun cahaya dapat terdistorsi. Pada transparent cahaya dapat tembus dan melewati permukaan tanpa hambatan dan distorsi. 
Tabel 1. The metaphor of transparency: The behavior of light as an analogy for communication of sustainable operational activities to stakeholders.

Sumber: Baldassarre \& Campo, (2016)

\begin{tabular}{lll}
\hline \multicolumn{1}{c}{ Opaque } & \multicolumn{1}{c}{ Translucency } & \multicolumn{1}{c}{ Transparent } \\
\hline & $\begin{array}{l}\text { Light can enter and } \\
\text { exit the surfaces the Light enters and exits }\end{array}$ \\
$\begin{array}{l}\text { Geology: light shining } \\
\text { on or through a piece } \\
\text { of mineral } \\
\text { the surfaces nor pass } \\
\text { through the structure } \\
\text { of the substance }\end{array}$ & $\begin{array}{l}\text { through its structure, substance and passes } \\
\text { partly obscured in the without alteration } \\
\text { passage }\end{array}$ \\
\hline
\end{tabular}

Beradasarkan metafora transparansi di atas, Baldassarre \& Campo (2016) membedakan perusahaan dalam 4 (empat) kuadaran dimana sumbu Y (vertikal) menggambarkan komitmen perusahaan untuk menjalankan sustainable initiatives sedangkan sumbu $\mathrm{X}$ (horisontal) menggambarkan bagaimana perusahaan mencoba untuk mengkomunikasikan sustainable initiatives kepada stakeholders (lihat Gambar 1).

Tidak ada peraturan baku yang dapat menetapkan bahwa sebuah perusahaan termasuk dalam kuadran tertentu karena masing-masing perusahaan memiliki keunikan dan tantangan tersendiri dalam menjalankan usahanya. Oleh karena itu, masing-masing perusahaan dapat melakukan penilaian secara mandiri untuk menentukan posisi perusahaan dalam kuadran. Selain untuk menentukan posisi, kuadran tersebut juga dapat digunakan untuk merumuskan strategi yang akan digunakan oleh perusahaan selanjutnya. Misalnya untuk perusahaan yang saat ini termasuk dalam translucent companies dapat mempertimbangkan kembali peran sustainability dalam marketing sehingga kedepannya perusahaan dapat bertransformasi menjadi transparent companies. Berikut terdapat beberapa pertanyaan yang dapat digunakan untuk melakukan analisa (Baldassarre \& Campo, 2016):

Tabel 2. A possible self-assessment checklist of commitment and communication for sustainability

Sumber: Baldassarre \& Campo (2016)

\begin{tabular}{ll}
\hline No & \multicolumn{1}{c}{ Checklists } \\
\hline 1 & How does your company define sustainability? \\
\hline 2 & Do you have an inventory of all the sustainability actions going on at your company? \\
\hline 3 & Do you have a sustainability strategy and goals? \\
\hline 4 & $\begin{array}{l}\text { Who is responsible for facilitating cross-departmental sustainability action and } \\
\text { communication? }\end{array}$ \\
\hline 5 & How is sustainability coordinated throughout the organization? \\
\hline 6 & Do you have systems in place for incorporating sustainability in decision-making? \\
\hline 7 & Do you have a program to educate employees regarding your sustainability standpoint? \\
\hline 8 & $\begin{array}{l}\text { Do you think that communicating your initiatives is important? Are you implementing a clear } \\
\text { communication strategy regarding your sustainability through different media? }\end{array}$ \\
\hline 9 & $\begin{array}{l}\text { What is the CEO's relationship to sustainability? Is this message aligned with actual } \\
\text { performance and future plans? }\end{array}$ \\
\hline
\end{tabular}

Berikut adalah uraian dari perusahaan yang masuk dalam masing-masing kuadaran (Baldassarre \& Campo, 2016): 


\section{Opaque Companies}

Perusahaan yang tergolong dalam opaque companies menyadari tentang peran sustainability dalam stategi pemasarannya sehingga perusahaan memilih untuk terlihat ikut berperan dan melakukan sustainable initiatives namun tanpa benar-benar melakukannya. Pada umumnya perusahaan melakukan hal tersebut karena adanya market external drivers seperti permintaan pelanggan, permintaan investor dan adanya tekanan persaingan serta non market external drivers seperti dari para aktivis lembaga swadaya masyarakat dan media. Opaque companies cenderung untuk fokus pada bagaimana mereka meningkatkan citra sehingga mereka akan menginformasikan tentang pencapaian yang mereka lakukan dan menutup-nutupi hal-hal yang dapat merusak citra mereka.

Dalam jangka pendek, perusahaan akan merasakan manfaat dari strategi tersebut, namun dalam jangka panjang perusahaan akan mengalami konsekuensi merugikan salah satunya adalah persepsi negatif dari para stakeholder yang menganggap bahwa perusahaan tidak memiliki kredibilitas. Selain itu, perusahaan juga dapat dikenakan sanksi atau pengetatan peraturan karena telah memberikan informasi yang tidak benar kepada stakeholder. Opaque companies biasanya dikenal dengan istilah perusahaan yang melakukan green washing.

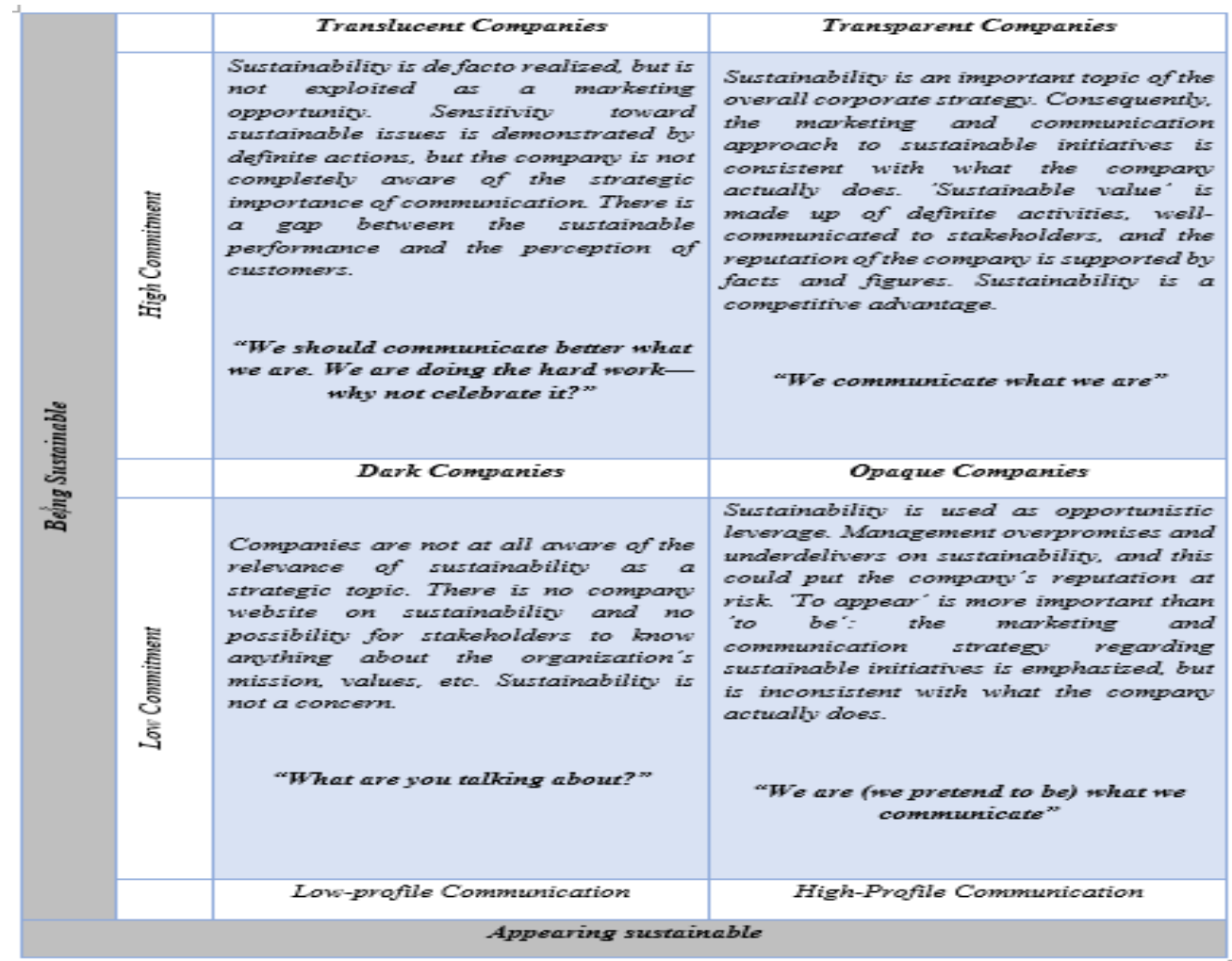

Gambar 1. A self-assessment tool for sustainable initiative transparency

Sumber: Baldassarre \& Campo (2016)

\section{Translucent Companies}

Perusahaan yang tergolong dalam translucent companies menyadari bahwa mereka memiliki kewajiban untuk melakukan sustainable initiatives sebagai bagian dari tanggung jawab mereka. Perusahaan cenderung menganggap bahwa membangun reputasi perusahaan berdasarkan komitmen untuk melakukan sustainability adalah hal yang tidak etis. Selain itu, perusahaan juga kawatir apabila hal tersebut dilakukan maka dapat merusak citra perusahaan dan berpotensi untuk dianggap melakukan manipulasi. 
Translucent companies tidak menyadari bahwa sustainability memiliki peran dalam strategi pemasaran dan mereka meyakini bahwa sustainable initiatives yang mereka lakukan tidak perlu diinformasikan kepada stakeholder. Berikut adalah risiko yang dapat dihadapi oleh translucent companies karena kurangnya sustainability communication:

- Perusahaan akan kehilangan kesempatan salah satunya dalam membukukan penjualan.

- Dengan tidak mengkomunikasikan sustainable initiatives yang telah dilakukan oleh perusahaan, hal tersebut dapat menimbulkan tantangan bagi perusahaan untuk menjalin hubungan dengan pelanggan karena tidak adanya informasi bahwa perusahaan juga telah mengambil bagian untuk menciptakan sustainability.

- Ketika tidak ada informasi yang tersedia, investor tidak dapat menemukan ketertarikan lebih terhadap perusahaan tersebut.

- Translucent companies akan terlihat tidak aktif apabila dibandingkan dengan opaque companies.

- Beban atas perusahaan yang tidak mempublikasikan sustainability efforts yang mereka lakukan tidak akan tergantikan.

- Ketakutan untuk dicap sebagai greenwashing companies karena menggunakan informasi tentang sustainability untuk meningkatkan citra perusahaan dapat mengambat perkembangan kegiatan usaha dan dapat berdampak negatif kedepannya.

\section{Transparent Companies}

Transparent companies mengomunikasikan apa dilakukan oleh perusahaan dan peran perusahaan terkait dengan sustainability. Apa yang disampaikan transparent companies sesuai dengan visi perusahaan dan sustainable initiatives yang telah dilakukan. Bagi transparent companies, sustainability yang telah dicapai bukan hanya sebagai biaya yang dikeluarkan oleh perusahaan namun juga sebagai kesempatan dan menjadi keunggulan bersaing untuk perusahaan. Hal tersebut dikarenakan terdapatnya peningkatan permintaan atas produk yang lebih ramah lingkungan (Baldassarre \& Campo, 2016).

Bagi transparent companies, sustainability telah menjadi salah satu tujuan yang ingin diwujudkan dalam perusahaan sehingga peran seluruh bagian dalam perusahaan tersebut menjadi penting. Untuk mewujudkannya, transparent companies mencoba untuk menerapkan prinsip sustainability dalam setiap kegiatan yang dilakukan seperti:

- Pemilihan pemasok dengan mempertimbangkan kontribusi pemasok terhadap sustainability.

- Proses dan kegiatan produksi yang juga mencoba untuk menggunakan teknologi yang ramah lingkungan.

- Penggunaan transportasi untuk keperluan logistik yang dikontrol sehingga dapat mengurangi emisi dan polusi.

- Perhatian terhadap hak asasi manusia seperti kesejahteraan dan keselamatan karyawan selama bekerja.

- Sumber daya yang dimiliki oleh perusahaan senantiasa dikelola dan dijaga dengan baik sesuai dengan peran dan kegunaannya.

- Dalam hal penelitian dan pengembangan, perusahaan juga senantiasa untuk mempertimbangkan unsur penggunaan teknologi yang sustainable.

Dapat disimpulkan bahwa transparent companies adalah perusahaan yang memahami peran sustainability sehingga perusahaan mengomunikasikan sustainable initiatives kepada stakeholder dengan tepat yang pada akhirnya diharapkan dapat digunakan sebagai marketing tool dalam menjalankan kegiatan usaha mereka. 


\section{Dark Companies}

Bagi perusahaan yang tergolong dalam dark companies, perusaaan tidak mengenal konsep sustainability dalam menjalankan kegiatan usahanya. Perusahaan tidak menyadari peran dari sustainability terhadap kelangsungan usaha dan menganggap bahwa isu tersebut bukanlah hal yang penting. Pada umumnya, perusahaan yang tergolong dalam dark companies adalah perusahaan kecil dan baru sehingga mereka tidak menganggap integrasi antara konsep sustainability dan kegiatan usaha yang dijalankan merupakan hal yang penting.

\section{METODE PENELITIAN}

Penelitian ini merupakan penelitian kualitatif. Sugiyono (2013) menjelaskan bahwa penelitian kualitatif merupakan penelitian naturalistik yang dilakukan pada kondisi yang alamiah. Adapun pendekatan yang digunakan dalam artikel ini adalah studi literatur yang dilanjutkan dengan studi kasus. Literatur yang ditelaah adalah literatur yang terkait dengan green marketing dan sustainability, sesuai dengan topik dan objek penelitian ini.

Kasus yang dipilih adalah kasus perusahaan yang beroperasi di Indonesia. Dalam hal ini subyek penelitian adalah dua perusahaan besar yang beroperasi di Indonesia yaitu PT Thermos Indonesia dan PT Unilever Indonesia Tbk. PT Thermos Indonesia merupakan perusahaan yang bergerak di bidang wadah vakum yang ramah lingkungan. Perusahaan ini merupakan pelopor untuk produk wadah vakum yang mengadopsi teknologi isolasi yang terdepan dengan desain yang inovatif yang mencerminkan gaya hidup konsumen saat ini. Adapun Merek Thermos® mulai masuk ke pasar pada tahun 1904 di Jerman dan kemudian berkembang menjadi salah satu merk unggulan di industrinya.

PT. Unilever Indonesia Tbk didirikan pada 5 Desember 1933 dan merupakan salah satu perusahaan yang bergerak di bidang produk konsumen atau tepatnya Fast Moving Consumer Goods (FMCG). Misinya adalah mengedepankan kehidupan yang sustainable yang diwujudkan dalam bentuk ramah lingkungan dan manfaat positif kepada masyarakat. Perusahaan ini telah memiliki program Sustainability yang mereka namakan Unilever Sustainable Living Plan (USLP).

Kedua perusahaan ini dipilih karena merupakan dua dari sedikit perusahaan di Indonesia yang menerapkan sustainability marketing dan merupakan contoh perusahaan yang tepat untuk menggambarkan bagaimana suatu perusahaan dapat survive di era pandemi Covid 19 ini. Sesuai dengan karakteristik penelitian kualitatif, jumlah kasus yang dipilih dianggap cukup apabila fenomena yang diteliti telah terjelaskan. Hycner (1985) bahkan mengatakan bahwa suatu riset kualitatif dianggap telah selesai apabila telah dicapai saturasi atau kejenuhan, walaupun hanya menggunakan satu case, satu responden, atau satu data saja.

\section{HASIL DAN PEMBAHASAN}

\section{Penerapan Sustainability sebagai Alat Pemasaran di Indonesia}

Baldassarre \& Campo (2016) mengatakan bahwa penggunaan konsep sustainability sebagai salah satu alat pemasaran dapat berpotensi menimbulkan citra tidak etis bagi perusahaan karena perusahaan dianggap mengeksploitasi konsep sustainability untuk mendapatkan profit. Lebih lanjut Baldassarre \& Campo (2016) menambahkan bahwa penggunaan konsep sustainability juga dapat dianggap untuk mempermudah bisnis yang dijalankan karena dengan menggunakan dan mengomunikasikan sustainable initiatives yang dilakukan oleh perusahaan, dari segi bisnis perusahaan dapat menarik investor atau pelanggan baru. Namun pada sisi lain terdapat pendapat yang mengatakan bahwa penggunaan konsep sustainability merupakan hal yang etis karena 
dengan memberikan informasi kepada para pemangku kepentingan, manajemen dapat membuat keputusan-keputusan seperti keputusan investasi atau pembelian produk berdasarkan informasi tersebut (Baldassarre \& Campo, 2016).

Meskipun terdapat pro dan kontra terhadap penggunaan sustainability sebagai alat pemasaran, namun tidak dapat dipungkiri bahwa untuk perusahaan yang termasuk dalam transparent companies penggunaan konsep tersebut memiliki dampak yang baik bagi perusahaan maupun bagi stakeholder. Bagi perusahaan, dengan mengusung konsep sustainability dalam menjalankan kegiatan usahanya selain perusahaan telah memenuhi tanggung jawabnya kepada lingkungan dan masyarakat, perusahaan juga memiliki kesempatan untuk meningkatkan brand image dan menarik perhatian stakeholder. Pada umumnya investor akan lebih tertarik untuk melakukan investasi pada perusahaan yang telah memiliki strategi sustainability karena hal tersebut menunjukkan bahwa perusahaan memiliki komitmen terhadap pelestarian lingkungan dan bukan hanya berfokus pada profitabilitas.

Selain itu calon konsumen saat ini juga cenderung lebih menghargai perusahaan yang peduli terhadap lingkungan sekitar. Dari sisi pelanggan juga akan diperoleh dampak positif, dengan memberikan informasi-informasi dan memproduksi produk yang ramah lingkungan, pelanggan dapat ikut berpartisipasi dalam menjaga dan melestarikan lingkungan dimana saat ini hal tersebut telah menjadi isu yang penting.

Ditengah pandemi Covid-19 ini, selain dampak negatif yang dialami oleh masyarakat seperti kondisi ekonomi yang mengalami penurunan terdapat juga dampak positif yang dirasakan yaitu semakin sadarnya masyarakat akan pentingnya menjaga lingkungan dan mengedepankan pola hidup sehat. Kebijakan-kebijakan yang dikeluarkan oleh pemerintah untuk memerangi pandemi Covid-19 mengubah kebiasaan masyarakat dan cara pandang terhadap kebersihan dan lingkungan. Seperti contohnya dengan melakukan social distancing dan physical distancing masyarakat menjadi mengurangi aktivitas di luar. Salah satu dampak dari kebijakan tersebut adalah berkurangnya penggunaan transportasi sehingga ikut juga mengurangi polusi.

Salah satu kasus yang diangkat dalam penggunaan sustainability marketing adalah praktek pemasaran pada PT. Thermos Indonesia. Perusahaan ini menyampaikan bahwa masyarakat mulai menyadari bahwa bencana dan wabah yang terjadi merupakan salah satu akibat dari alam yang mulai kehilangan keseimbangannya (Media Indonesia, 2020). Oleh karena itu, perusahaan Thermos senantiasa mengajak masyarakat untuk mengurangi penggunaan botol plastik dan mulai menggunakan botol minuman sendiri yang aman bagi kesehatan dan lingkungan.

PT Thermos Indonesia berusaha untuk menggunakan konsep sustainability marketing ditengah pandemi Covid-19 dengan mengajak konsumen untuk membeli botol minum yang diproduksi oleh perusahaan. Botol minum tersebut diklaim sebagai produk berbahan stainless steel yang ramah lingkungan dan aman bagi kesehatan serta tidak mengandung bahan plastik yang berbahaya dan tidak ramah lingkungan. Selain ramah lingkungan, perusahaan juga menginformasikan bahwa botol tersebut baik bagi kesehatan konsumen karena dengan menggunakan botol milik sendiri dan tidak membeli minuman kemasan maka dapat membantu pelanggan dalam mengurangi risiko penularan virus Covid-19.

Contoh lain, PT Unilever Indonesia Tbk melalui kegiatan CSR-nya juga berupaya untuk tidak hanya memenuhi tanggung jawab perusahaan terhadap konsumen dan lingkungan namun juga sustainable initiatives yang telah dilakukan khususnya selama pandemi Covid-19 ini. 
Programnya adalah bantuan paket produk kebersihan melalui "Gerakan Masjid Bersih", penyediaan produk cuci tangan untuk rumah sakit dan turut serta dalam mendisinfeksi lingkungan melalui program "Gerakan Sekolah Bersih" dan "Gerakan Bersih Lingkungan" (Unilever, 2020b). Perusahaan berusaha untuk mengkomunikasikan peran yang diambil oleh perusahaan untuk konsumen dan lingkungan. Di sisi lain perusahaan juga menggunakan pendekatan ini sebagai salah satu strategi pemasaran dalam memberikan edukasi kepada konsumen terkait dengan produk-produk Unilever.

Untuk lebih mewujudkan komitmen terhadap sustainability, pada tahun 2010 Unilever telah meluncurkan Unilever Sustainable Living Plan yang merupakan strategi untuk terus mengembangkan bisnisnya seraya mengurangi dampak negatif terhadap lingkungan dan meningkatkan dampak sosial yang positif bagi masyarakat (Unilever, 2020a). PT Unilever Indonesia Tbk merupakan salah satu contoh dari sekian banyak perusahaan di Indonesia yang termasuk dalam transparent companies dimana perusahaan memiliki komitmen dan komunikasi terkait dengan sustainability.

Selain perubahan cara berpikir konsumen yang lebih peduli terhadap isu kesehatan dan lingkungan, pandemi Covid-19 juga mengubah cara berperilaku masyarakat dalam berbelanja. Untuk tetap bertahan ditengah pandemi Covid-19, para pelaku usaha dapat menyiasatinya dengan mulai fokus pada pemasaran digital melalui website yang dijadikan $e$ commerce, social media dan search engine (Aryanto, 2020). Yang juga perlu menjadi perhatian adalah, umumnya konsumen saat ini telah menjadi pengguna media sosial, terutama konsumen usia muda. Penetrasi media sosial telah sedemikian tinggi, bahkan telah juga digunakan oleh organisasi keagamaan (Pratama \& Chairy, 2020).

Pasca pandemi Covid-19, perilaku konsumen yang terbentuk saat ini akan bertahan hingga kondisi the next normal. Kebiasaan yang dilakukan konsumen seperti diuraikan di atas akan terus berlanjut.Oleh karena itu, untuk memenuhi dan menjawab permintaan pelanggan sebaiknya para pelaku industri juga mulai melakukan penyesuaian strategi pemasaran. Selain memperhatikan kebiasaan konsumen yang terus terbawa hingga era the next normal yaitu dalam hal kebiasaan online, perusahaan juga perlu menggunakan konsep sustainability marketing, dengan demikian diharapkan perusahaan dapat bertahan dan berkembang pasca pandemi Covid-19 di Indonesia.

\section{KESIMPULAN DAN SARAN \\ Kesimpulan}

Konsep sustainability as a marketing tool dapat dianalogikan kedalam istilah yang digunakan dalam geologi yaitu opaque companies, translucent companies, transparent companies, dan dark companies. Komunikasi dalam konsep sustainability memiliki peran yang penting bagi perusahaan. Apabila perusahaan tidak dapat mengomunikasikan strategi sustainability yang digunakan kepada pihak eksternal seperti pemasok, investor, dan pelanggan, maka perusahaan dapat kehilangan kesempatan untuk membukukan penjualan atas pelanggan yang peduli terhadap produk yang ramah lingkungan yang terus mengalami peningkatan permintaannya. Sustainability dapat menjadi alat pemasaran yang efektif_dengan satu syarat yaitu perusahaan harus percaya bahwa mereka dapat merealisasikannya dan perusahaan harus memiliki strong ethical values agar perusahaan tersebut dapat berhasil dalam melakukan transisi dari level moral ke level kuantitatif. Sustainability marketing dapat digunakan oleh perusahaan untuk mempertahankan eksistensinya pasca pandemi Covid-19 dengan tetap memperhatikan perubahan perilaku pelanggan di era the next normal. 


\section{Saran}

Mempertimbangkan ampuhnya sustainability sebagai alat pemasaran, maka para pemasar di Indonesia dalam era the next normal tidak perlu ragu untuk mengadopsi pendekatan ini. Contoh kasus di atas memperlihatkan kesesuaian antara alat pemasaran yang digunakan (sustainability) dengan situasi lingkungan dan karakteristik konsumen. Karenanya, dengan mengacu pada best practices perusahaan yang telah lebih dulu mengadopsi sustainability dalam strategi pemasaran mereka, berbagai perusahaan yang belum menerapkannya tidak perlu ragu lagi untuk mengambil langkah serupa.

\section{REFERENSI}

Aryanto, A. (2020). Di tengah Covid-19, pemasaran online dan digital branding jadi pilihan. Warta Ekonomi. https://www.wartaekonomi.co.id/read280988/di-tengah-covid-19pemasaran-online-dan-digital-branding-jadi-pilihan

Baldassarre, F., \& Campo, R. (2016). Sustainability as a marketing tool: To be or to appear to be? Business Horizons, 59(4), 421-429. https://doi.org/10.1016/j.bushor.2016.03.005

Bhaskar, H. L. (2013). Green marketing: A tool for sustainable development. International Journal of Research in Commerce \& Management, 4(06).

Chairy, C., \& Alam, M. E. N. (2019). The influence of environmental concern, green perceived knowledge, and green trust on green purchase intention. Jurnal Manajemen (Edisi Elektronik), 10(2), 131-145. DOI: http://dx.doi.org/10.32832/jm-uika.v10i2.2431

Farez, A. (2018). Sustainable marketing for better world. Kompasiana. https://www.kompasiana.com/adrinfarez/5b044d84dd0fa812340af542/sustainabemarketing-for-better-world

Hycner, R. H. (1985). Some guidelines for the phenomenological analysis of interview data. Human Studies, 8(3), 279-303

Jeevan, P. (2016). A study on marketing and sustainability - A case study approach with reference to Hindustan Unilever Limited. International Journal of Scientific Research and Modern Education (IJSRME), I(I), 2455-5630. https://poseidon01.ssrn.com/delivery.php?ID=2511110651111091240000800850760730 86027042005049030031109121093102123009023011120113025043060052010029015 01911009509001211808101101505703706712207600300212010008111207003902111 11140900231101250841120011270831221

Kotler, P., \& Keller, K. L. (2016). Marketing management. 15th ed., London: Pearson Education Limited.

Media Indonesia. (2020). Masyarakat diimbau peduli lingkungan di tengah pandemi Covid-19. Media Indonesia. https://mediaindonesia.com/read/detail/308271-masyarakat-diimbaupeduli-lingkungan-di-tengah-pandemi-covid-19

Mukhaer, A. A. (2020). \#DiRumahAja Saat Wabah COVID-19, Polusi Udara Jakarta Berkurang. National Geographic. https://nationalgeographic.grid.id/read/132074944/dirumahaja-saat-wabah-covid-19polusi-udara-jakarta-berkurang

Pearce II, J. A., \& Robinson Jr., R. B. (2015). Strategic management: Planning for domestic \& global competition (14th ed.). Boston: McGraw-Hill Education.

Pratama, S., \& Chairy, C. (2020). Media komunikasi pemasaran pada institusi Gereja (Analisis terhadap peran Instagram). Jurnal Muara Ilmu Ekonomi dan Bisnis, 4(1), 137-144. DOI: 10.24912/jmieb.v4i1.7683

Sugiyono, S. (2013). Metode penelitian kualitatif. Bandung: Alfabeta.

Syahrivar, J., \& Ida, S. (2019). Does the green image enhance student satisfaction? (Evidence from Indonesia). The New Educational Review, 57(3), 52-62. DOI: 
10.15804/tner.2019.57.3.04

Unilever. (2020a). Kehidupan Berkelanjutan. Unilever. https://www.unilever.co.id/sustainableliving/

Unilever. (2020b). Unilever Ambil Peran Dalam Melindungi Masyarakat Indonesia dari Pandemi COVID-19. Unilever. https://www.unilever.co.id/news/pressreleases/2020/unilever-ambil-peran-dalam-melindungi-masyarakat-indonesia-daripandemi-covid-19.html

Unruh, G., \& Ettenson, R. (2010). Growing green. Harvard Business Review. https://hbr.org/2010/06/growing-green 